\title{
Co-Teaching in the Academy-Class Program: From Theory to Practical Experience
}

\author{
Yonit Nissim $^{1} \&$ Edni Naifeld ${ }^{1}$ \\ ${ }^{1}$ Ohalo Acdemic College, Israel \\ Correspondence: Yonit Nissim, Ohalo Acdemic College, Israel.
}

Received: April 3, 2018

Accepted: May 10, $2018 \quad$ Online Published: May 15, 2018

doi:10.5539/jel.v7n4p79

URL: https://doi.org/10.5539/jel.v7n4p79

\begin{abstract}
This study focuses on implementing co-teaching models in the practical experience of teacher training processes. It examines the experience models in terms of theory versus practice from the perspectives of students of education and training teachers (school and pre-school) who participated in the special "Academy-Class" program in the 2017 academic year at Ohalo College. 125 subjects participated in the study. The overriding goal of the research was to identify the dominant patterns in this unique practical experience in teachers training. The research questions sought to clarify the extent to which the six main co-teaching models described in the research literature are manifested in practical and educational terms in the Academy-Class program; offer a comparison between common teaching practices and the co-teaching models; and assess how common Synergetic Collaboration is as a co-teaching method relative to other low-level methods.

Our findings show that the co-teaching models were more dominant than the traditional teaching models among all the sample groups. The greatest difference was found in the reports of the training teachers $(0.79)$ at the school, while the smallest difference was found among students training to become teachers $(0.13)$. We have seen that experiencing a clinical model of co-teaching involves shared work between a training teacher and of a student of education. There is a need to change training processes, as well as expanding the theoretical approaches that describe the wide range of shared co-teaching.
\end{abstract}

Keywords: teachers' training, teaching methods, practical experience

\section{Introduction}

\subsection{Co-Teaching}

Bacharach, Heck, \& Dank (2004) defined co-teaching as a situation where two teachers (a training teacher and a trainee teacher or student of education) work together in one classroom on planning, organization, and implementation. Cook and Friend (1995) expanded this definition to include two or more teachers teaching together in significantly different ways which are intended to reach a diverse group of students, all in one physical space. Wenzlaff et al. (2002) emphasized the benefits of this teaching method, in terms of teaching lessons that cannot be taught alone. One application of the co-teaching model refers to co-teaching between training teachers and students of education. In such a case, the recommendation is to divert from a traditional practical experience, which would emphasize a hierarchy between trainer and student, to use a process where both partners share teaching and other responsibilities in the classroom (Roth \& Tobin, 2005).

As shown in the literature, co-teaching offers several advantages. As one teacher receives significant assistance from another and shares the work with him or her, the students receive greater learning opportunities and significant mediation (Arbiv-Elyashiv, 2013; Forbes \& Billet, 2012). In this way, the model provides additional assistance to weak students and enrichment to students who are above the class level. Studies on the influence of co-teaching on student achievement found an advantage in math achievement among students in co-teaching classrooms, compared to students in regular classrooms (Bacharach, Heck, \& Dahlberg, 2010; Forbes \& Billet, 2010).

In addition, the training teachers reported authentic and significant professional development within co-teaching. Their daily interactions with students of education required constant discussion and reflection on teaching, revitalized their teaching methods, and encouraged the students of education to expand their roles as leaders in the school (Gallo-Fox \& Scantlebury, 2016). In addition, co-teaching within an environment of mutual respect, 
emotional support, and trust gives the added value of constructing the teacher's identity, sharpening and deepening his or her knowledge of the teaching material, and raising the level of the actual teaching (Wehunt \& Weatherford, 2014). Students who were exposed in their training to co-teaching methods reported a gradual integration into the classroom, which focused on the connection between theory and practice. The students further reported that the experience enabled mutual learning and that co-teaching provides a supportive environment for professional and in-depth teaching (Arbiv-Elyashiv, 2013; Forbes \& Billet, 2012; Rytivaara \& Kershner, 2012).

Co-teaching's success depends on several elements, notably shared work that includes planning, organization, and assessment. Shared planning is extremely important for co-teaching, so sufficient time and attention must be allocated for this stage (Kamens, Susko, \& Elliott, 2013). At first, the teacher will manage the planning, but over time the student of education will become responsible for a greater part in this process (Bacharach et al., 2010). Each of the co-teaching partners will contribute his or her personal talents and skills (Murawski \& Lochner, 2011). Following the lesson, the training teachers will assess and reflect on the process, and receive feedback from the students of education. Interpretation and analysis will clarify to the student of education what occurred and direct him or her to additional teaching strategies and techniques (Murawski \& Lochner, 2011; Scantlebury, Gallo-Fox, \& Wassell, 2008).

\subsubsection{Models for Co-Teaching as Part of Teaching Practice}

"One teacher teaches and the other observes": the senior and more experienced trainer leads the lesson, while the student of education integrates gradually, mainly by observing lessons and then experiencing private, group, and full-class teaching. The student of education learns by observing an experienced model, hearing the responses of the students in the class, and analyzing the lesson (Bacharach et al., 2010; Cook \& Friend, 1995; Graziano \& Navarrete, 2012).

"Head teacher teaches and the other teacher supports": the trainer takes the main responsibility for the lesson and teaches the material. The student of education moves among the students in the class, helps them with their work, and explains and elaborates on the material as needed (Bacharach et al., 2010; Cook \& Friend, 1995; Graziano \& Navarrete, 2012; Walsh \& Johns, 2004).

"Parallel teaching": In this model, both teachers teach an identical lesson simultaneously to two separate groups of students (Cook \& Friend, 1995; Graziano \& Navarrete, 2012; Villa, Nevin, \& Thousand, 2004).

"Teaching in stations": the trainer and student of education split up the students in the class and the content that each of them will teach. The students in the class move from one learning station to the next.

"Variable teaching": one teacher teaches the entire class, while the second teaches a single student or a small group of students at the same time.

"Group teaching": the trainer teacher and the student of education share the responsibility to teach the same content simultaneously to the same group of students. According to this model the teachers use the same teaching methods, such as turns, role playing, examples, etc. (Bacharach et al., 2010; Cook \& Friend, 2004).

\subsubsection{From Low-Level Co-Teaching to Synergetic Co-Teaching}

Among the teaching methods mentioned above, we find several that reflect a low level of collaboration: one teacher is dominant and leads the lesson, while the second is supportive but more passive. Tov-Li \& Frisch (2008) noted that while this is the traditional model of co-teaching, it risks involving no co-teaching at all, in contrast to the more complex models of parallel teaching or teaching in stations, where each teacher works separately from his or her colleague.

In this regard, Sachs, Fisher, \& Canon (2011) introduced the value of synergetic collaboration. They claimed that such collaboration must include clear consent, mutual collaboration in growth processes, and a contribution to mutual development. Recent approaches define the term synergetic co-teaching as teaching that is adapted to the educational needs of the twenty-first century. In an age when the skills required from workers emphasize teamwork, problem solving, and interpersonal relationships (De Fruyt, Wille, \& John, 2015), high-level collaborative teaching, which involves in-depth cooperation between two teachers, strengthens an innovative teaching approach that prepares students to be independent and multidisciplinary, able to learn in diverse locations and styles (Amar \& Ben-David, 2016; Brown, 2016).

Schools around the world have tried to apply diverse models of co-teaching in their classes. Over the last decade, many educational researchers have explored and evaluated these co-teaching models, which have changed according to the dynamic needs and trends of twenty-first century education. The present study belongs to the 
broad field of education, and specifically to the practical section of this field addressing teaching practice in teacher training processes. In this part of their training, the students go out to schools and pre-schools, accompanied by training teachers, and undertake clinical practice. The study moves from theory to practice, examining what happens in the teaching field, and focusing on a special program called the Academy-Class. This program began to operate in 2015 on the initiative of the Ministry of Education, and its goals are to improve teacher training processes; promote a transition to co-teaching in classrooms; and to emphasize practical and cooperative experience in real conditions in pre-schools and schools. All these seek to prepare the future teachers for their teaching work in the best possible manner. The students' teaching practice takes place three times a week in the educational institutions. Each student has a training teacher who provides close supervision during the field training process. Cooperative work is manifested in lesson planning, co-teaching, guidance and training, and reflection. Due to the innovative nature of this teaching practice model, it is highly relevant to enhance the research by examining a case study that begins from the theoretical standpoint and realizes the theory in clinical practice in the educational field. This study examines the practical implementation of the program. During their teacher training, the students receive a "toolbox" of teaching methods suitable for the twenty-first century; accordingly, it is important to examine whether what they learn is actually implemented in the field.

\subsection{Strengthening the Connection between Theory and Practice}

Although the subject of teacher training has been discussed in depth, this study is the first of its kind, and accordingly its findings cannot be compared to those of previous studies in the field. The study is particularly important since its findings will enhance the understanding and conceptualization of the theoretical and practical framework for teacher training processes. The findings will illuminate and conceptualize training teachers and students training to be teachers and to gain a deeper understanding of different approaches to co-teaching. They will refine our insights into the teacher training process in general, and in particular provide conclusions and insights concerning the Academy-Class program.

Several studies have spotlighted the significance of mutual relationships between teachers (Blank, 2013; Cleaveland, 2015; Petrick, 2015). In order to test this claim and shed more light on the subject, there is a need to expand the existing data. Accordingly, the current study aims to highlight the co-teaching models from a different angle within the framework of teacher training, by evaluating both theory and practice in a unique practical experience program at Ohalo College.

\subsection{Hypotheses and Research Questions}

We hypothesized that: 1) It will be found that cooperative teaching models were more dominant than traditional models. 2) It will be found that there is still a gulf between the cooperative teaching models and models reflecting synergetic teaching.

In order to test these hypotheses, we formulated the following research questions:

1. To what extent are the six co-teaching methods represented in a unique practical experience program, from the teachers and students' perspectives?

2. How do the most common teaching practices, according to training teachers and students' (who are participating in the program) reports, compare to the co-teaching models?

3. How common is synergetic collaboration as a co-teaching method, by comparison to other low-level methods?

In order to answer the research questions and examine the hypotheses in depth, a study was designed based on a structured and validated questionnaire (content validation showed content face validity). The results of the study were processed, several statistical tests were applied, and the quantitative findings presented in numerical and graphical form. The findings sample the different teaching models used in the unique teaching practice in the Academy-Class at Ohalo College.

\section{Method}

At the end of the 2016-2017 school year, a questionnaire was sent via Google Drive to the participants -140 students of education (trainee teachers) and 100 training teachers and pre-school teachers as part of the teaching practice undertaken by the third-year students of education. Of these recipients, 125 subjects completed the questionnaire, as detailed in table 1: 36 students of education, 20 students of early childhood education, 51 training teachers, and 18 training pre-school teachers.

\subsection{Socio-demographic Profile of the Research Participants}

Training teachers: The participants included 51 training teachers and 18 trainer preschool teachers; 80 percent of the participants teach in elementary schools and 20 percent in pre-schools and post-elementary schools. The 
average age is 40 and the participants have an average seniority of 13 years in teaching; 85 percent are women and 15 percent men. The participants are all residents of the north of Israel (Galilee, Golan Heights, and Beit Shean Valley) employed in the Ministry of Education's Northern District.

Students of education: The participants included 56 students, with an average age of 25 . The participants were third-year students in various teacher training programs (B.Ed. in Education and Teaching). All the participants are residents of the north of Israel; 80 percent are women and 20 percent men.

Table 1. Respondents' fields of specialization

\begin{tabular}{lcc}
\hline Field of Specialization & Students of education & Trainers (school / pre-school teachers) \\
\hline Early Childhood & 20 & 18 \\
Judaism & 18 & 2 \\
English & 10 & 16 \\
Science & 4 & 19 \\
Mathematics & 2 & 5 \\
Biology & 2 & 1 \\
Physical Education & & 1 \\
Israel Studies & & 7 \\
General education & & 1 \\
\hline
\end{tabular}

\subsection{Sampling Procedures}

Single-stage sampling was undertaken through the convenience sampling of the teacher training institute (Ohalo College). All the participants in the Academy-Class were sampled. The questionnaire was distributed to the participants via Google Drive and replies were anonymous in order to avoid ethical issues. Anonymity allows the students to respond freely and to express their true opinions. This was particularly important since the researchers are also the directors of the program at the College, alongside their function as academic and researchers.

Validation of the questionnaire, showing content face validity, was undertaken by three experts in the content field, all of whom hold Ph.D. degrees. The statements were constructed in a manner permitting the empirical evaluation of the various theoretical approaches.

\subsection{Research Design}

The research tool was a validated questionnaire that included a series of 13 statements based on a Likert scale (1-5). For all statements, the highest value (5) represents high incidence and the lowest value (1) represents low incidence. Average values were calculated for all responses, while t-tests were used to identify significance. In the first stage, the 13 statements described the traditional model (that does not include co-teaching) as well as the seven co-teaching models detailed in the literature. The variable teaching model was divided into two sub-models, in which one teacher teaches the entire class and the second teacher teaches either a small group or just one or two students. 
Table 2. Distribution of statements into content categories

\begin{tabular}{|c|c|c|}
\hline Model of teaching practice & Item & Content of statement \\
\hline \multirow{2}{*}{$\begin{array}{l}\text { Traditional model of experience - one } \\
\text { teacher teaching }\end{array}$} & 1 & The teacher teaches and I sit passively. \\
\hline & 2 & I teach and the teacher sits passively. \\
\hline \multirow{2}{*}{$\begin{array}{l}\text { Model } 1 \text { - One teacher teaches and } \\
\text { the other observes }\end{array}$} & 3 & The teacher teaches and I observe him/her and/or the other students. \\
\hline & 4 & I teach and the teacher observes me and/or the other students. \\
\hline \multirow{2}{*}{$\begin{array}{l}\text { Model } 2 \text { - One teacher teaches and } \\
\text { the other supports on the side }\end{array}$} & 5 & $\begin{array}{l}\text { The teacher teaches and I support him/her on the side, helping the } \\
\text { students. }\end{array}$ \\
\hline & 6 & I teach and the teacher supports me on the side, helping the students. \\
\hline $\begin{array}{l}\text { Model } 3 \text { - Two teachers teach the } \\
\text { same material simultaneously in two } \\
\text { separate groups (parallel teaching) }\end{array}$ & 7 & $\begin{array}{l}\text { The teacher and I teach the same material simultaneously in two separate } \\
\text { groups. }\end{array}$ \\
\hline $\begin{array}{l}\text { Model } 4 \text { - Two teachers teach } \\
\text { different material to two groups in } \\
\text { "stations" }\end{array}$ & 8 & The teacher and I teach different material in two groups in "stations." \\
\hline \multirow{2}{*}{$\begin{array}{l}\text { Model } 5 \text { - One teacher teaches most } \\
\text { of the class while the other teaches a } \\
\text { small group }\end{array}$} & 9 & The teacher teaches most of the class while I teach a small group. \\
\hline & 10 & I teach most of the class while the other teacher teaches a small group. \\
\hline \multirow{2}{*}{$\begin{array}{l}\text { Model } 6 \text { - One teacher teaches the } \\
\text { whole class while the other teacher } \\
\text { works with one or two students }\end{array}$} & 11 & $\begin{array}{l}\text { The teacher teaches the whole class while I work with one or two } \\
\text { students. }\end{array}$ \\
\hline & 12 & $\begin{array}{l}\text { I teach the whole class while the other teacher works with one or two } \\
\text { students. }\end{array}$ \\
\hline $\begin{array}{l}\text { Model } 7 \text { - Two teachers teach the } \\
\text { class together simultaneously (Group } \\
\text { Teaching) }\end{array}$ & 13 & The other teacher and I teach the class together simultaneously. \\
\hline
\end{tabular}

In the second stage, the models were mapped by their level of co-teaching and grouped into three categories, from lack of co-teaching to synergetic co-teaching, as detailed in table 3 .

Table 3. Model categories by level of co-teaching

\begin{tabular}{ll}
\hline Category & Models \\
\hline No co-teaching at all & Traditional experience model - one teacher only. \\
\hline $\begin{array}{l}\text { Low-level co-teaching (one } \\
\text { teacher is more dominant } \\
\text { than the other) }\end{array}$ & $\begin{array}{l}\text { Model } 1 \text { - one teacher teaches and the other observes him/her } \\
\text { Model } 2 \text { - one teacher teaches and the other supports him/her on the side } \\
\text { Model } 6 \text { - one teacher teaches the whole class and the other teaches one or two students }\end{array}$ \\
\hline $\begin{array}{l}\text { Synergetic co-teaching } \\
\text { two active teachers, equal } \\
\text { partners, contributing equal } \\
\text { values) }\end{array}$ & $\begin{array}{l}\text { Model } 3 \text { - two teachers teach the same material simultaneously to two separate groups } \\
\text { Model } 7 \text { - two two teachers teach the same material to two groups in "stations" }\end{array}$ \\
\hline
\end{tabular}




\section{Results}

The following tables present the subjects' average responses to all the statements for each of the four groups.

\subsection{Results for the First Research Question}

To what extent are the six main co-teaching models (as described in the research literature) expressed in practical and educational terms in the Academy-Class program?

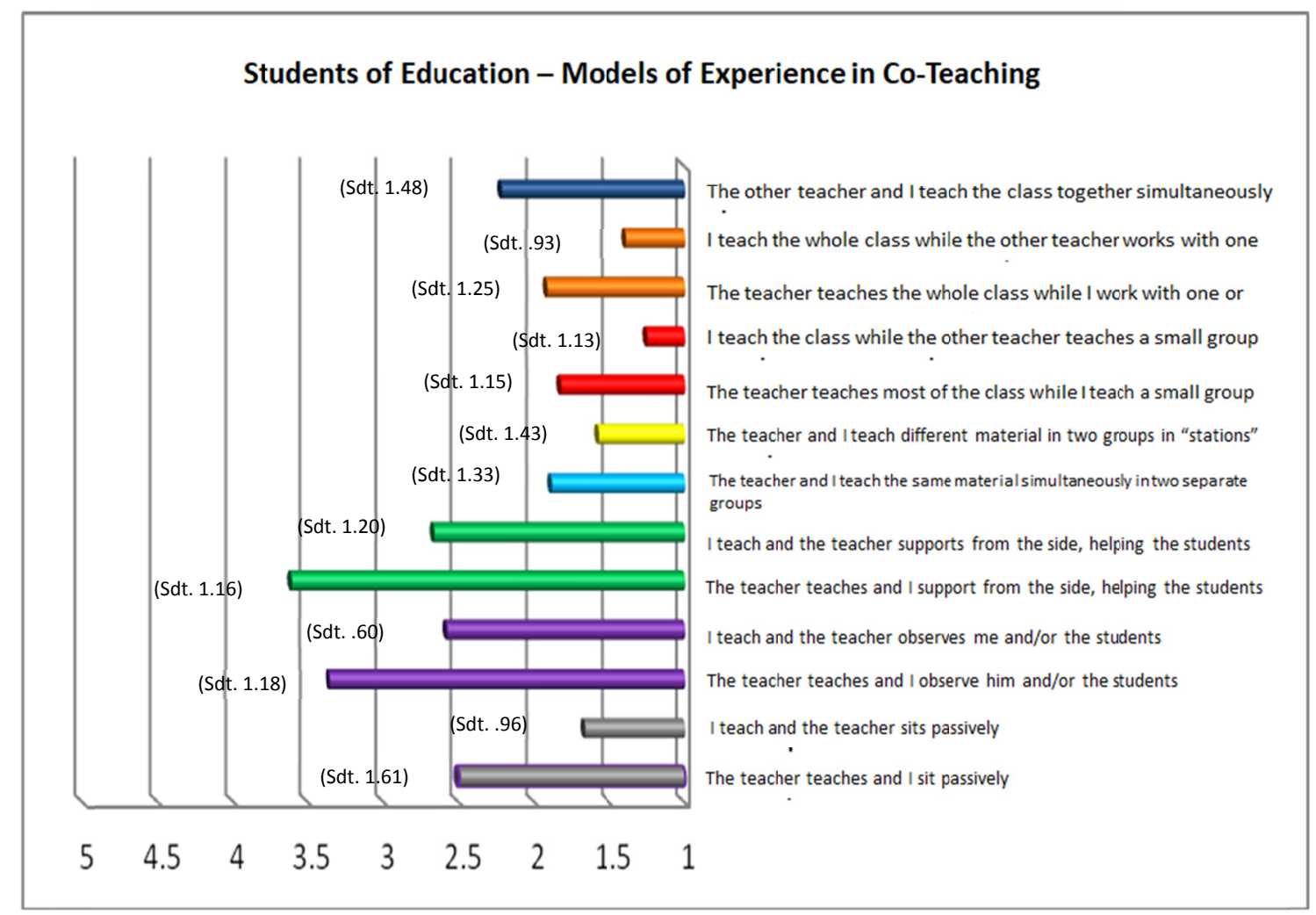

Figure 1. Students of education - average incidence of co-teaching 


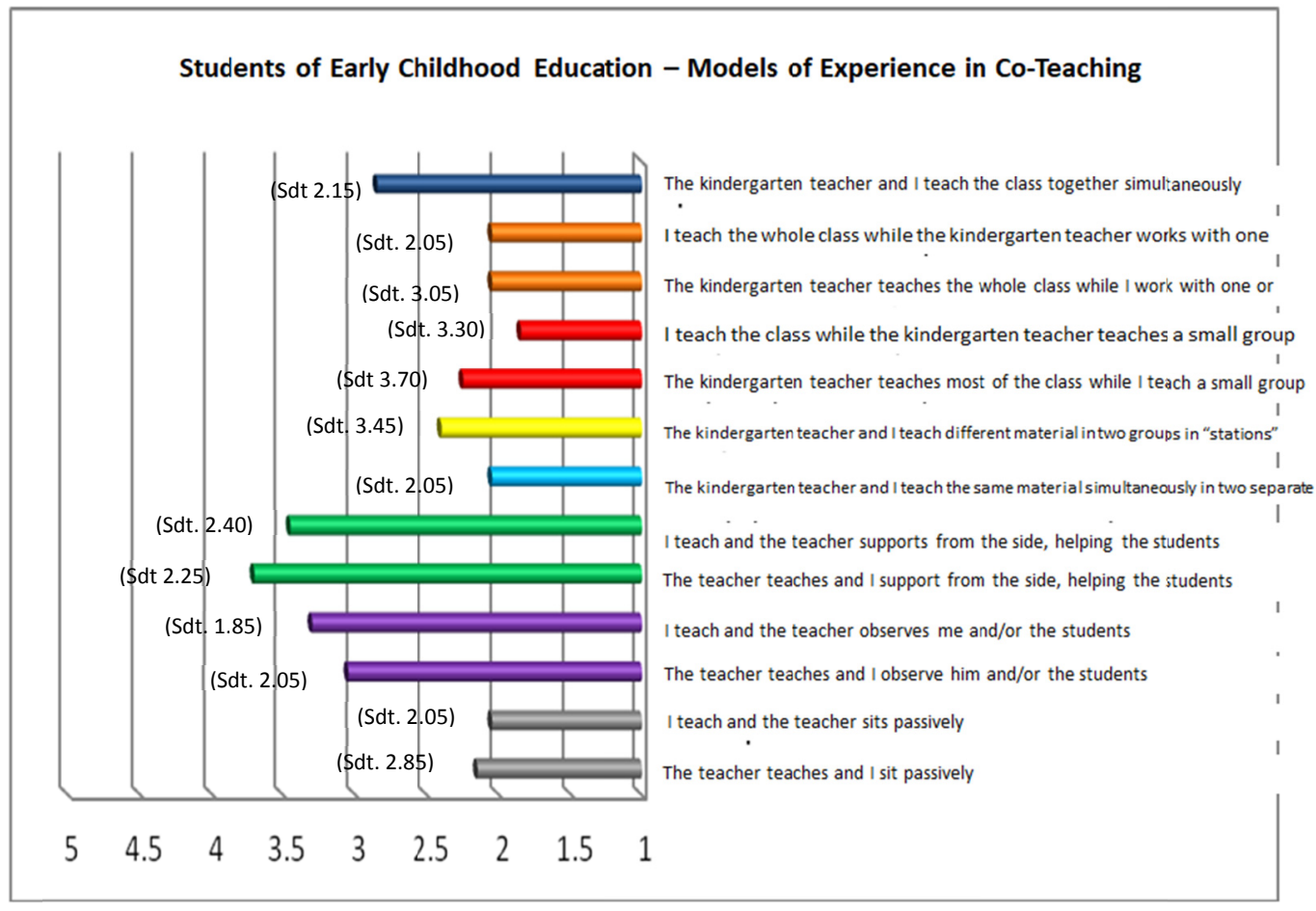

Figure 2. Students of early education - average incidence of co-teaching

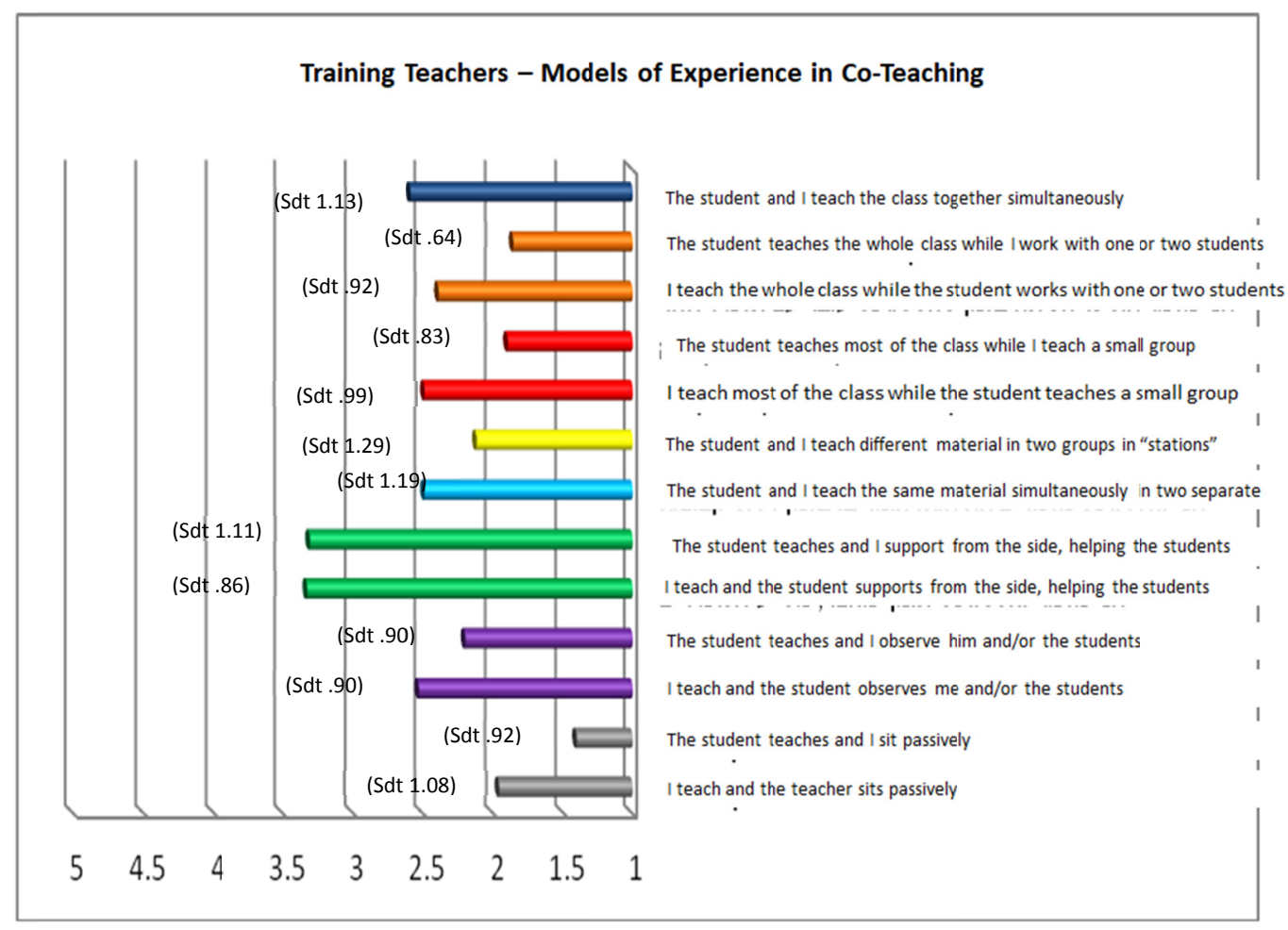

Figure 3. Training teachers - average incidence of co-teaching 


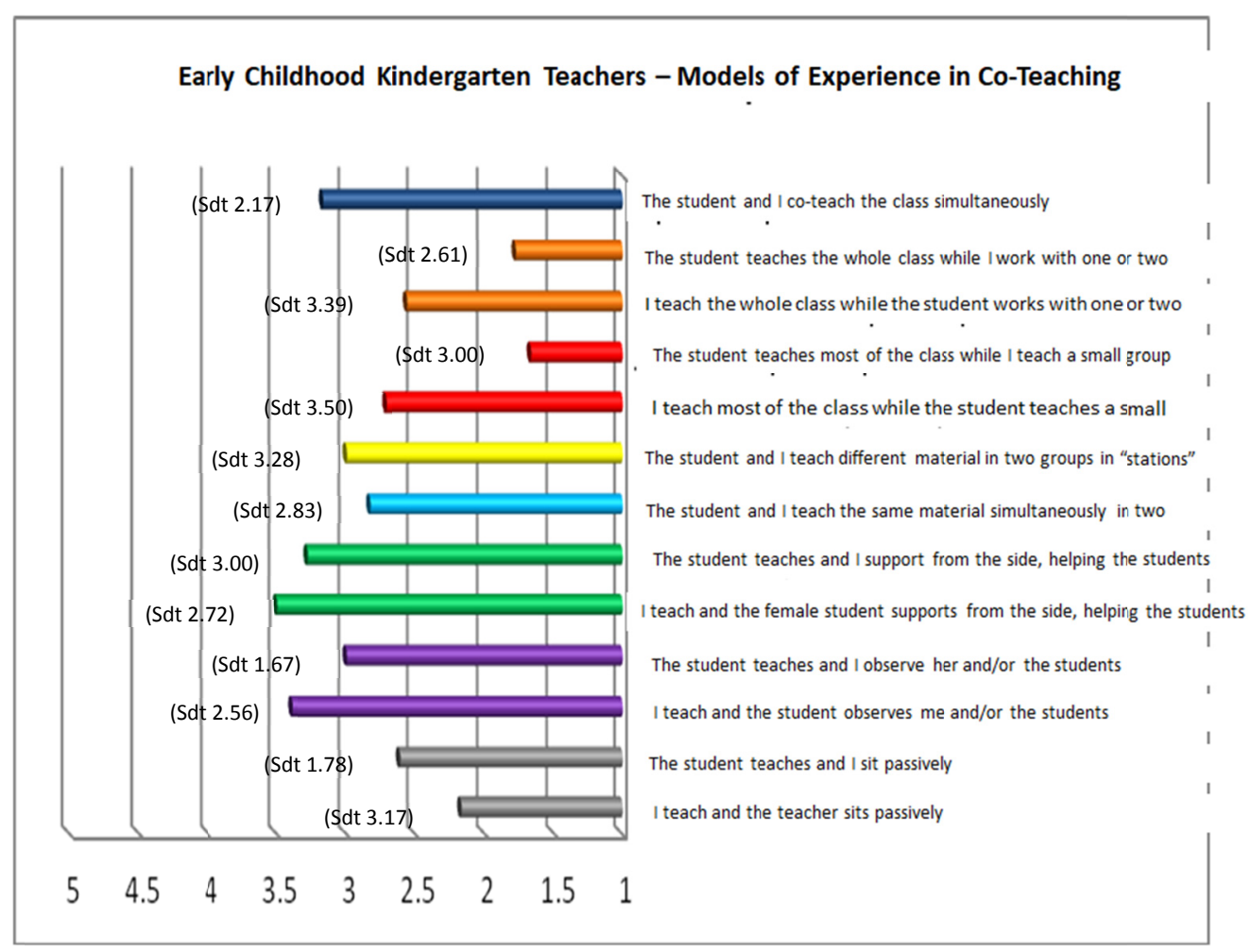

Figure 4. Pre-school teachers - average incidence of co-teaching

\subsection{Results for the Second Research Question}

How do the most common teaching practices, as reported by the training teachers and students of education in the program, compare to the co-teaching models?

We will now present the averages of the traditional statements and the averages of the co-teaching statements. Statements 1-2, as they appear in the research questionnaire, indicate "traditional teaching" (a teaching model that does not include co-teaching at all), while the remaining statements (3-13) indicate co-teaching. Figure 5 below displays the averages of these two indices among the four groups. 


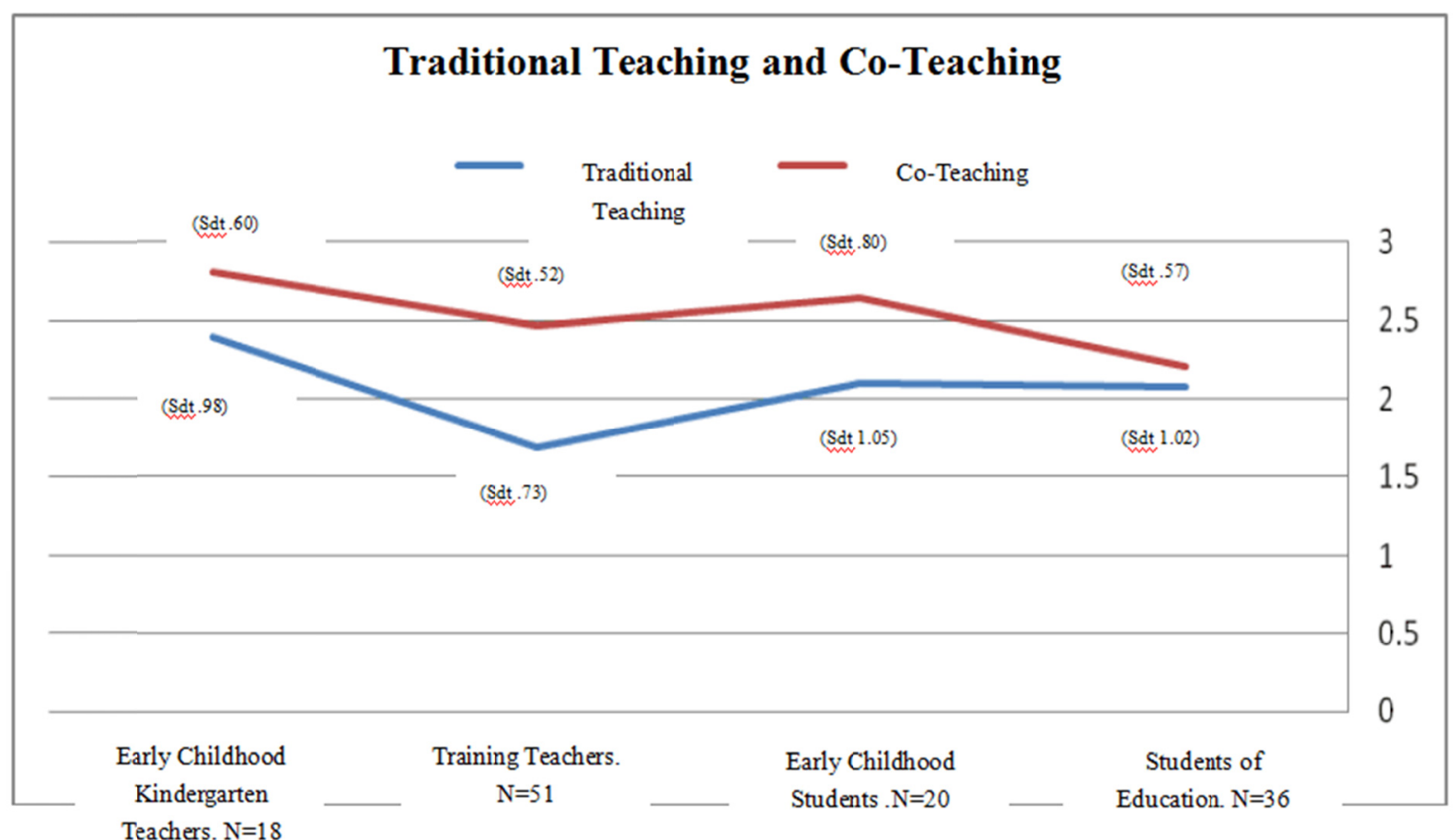

Figure 5. Traditional teaching and co-reaching in the four groups

A higher level of incidence was found for co-teaching than for traditional teaching in all groups. In particular, the highest difference in schools was among the training teachers $(0.79)$, while the lowest difference was among students of education (0.13). The t-test found significant diversity in between the teachers' group and the students' group: $\mathrm{t}(85)=2.56, \mathrm{p}<0.05$.

On the other hand, in pre-schools the difference among the students (0.54) was higher than that among the pre-school teachers $(0.42)$. The t-test found non-significant diversity in the co-teaching vs. traditional teaching difference between the students and the pre-school teachers: $\mathrm{t}(36)=0.29, \mathrm{p}>0.05$.

\subsection{Results for the Third Research Question}

How common is Synergetic Collaboration as a co-teaching method, in comparison to other low-level methods?

As stated above, the co-teaching statements, items 3-13 in the questionnaire, were divided into low-level co-teaching and synergetic co-teaching groups. Table 4 compares the averages of the low-level co-teaching statements with those of the synergetic co-teaching statements.

Table 4. Low-level co-teaching and synergetic co-teaching in the four groups

\begin{tabular}{|c|c|c|c|c|c|c|c|}
\hline . & \multicolumn{3}{|c|}{ Low-level co-Teaching } & \multicolumn{4}{|c|}{ Synergetic Co-Teaching } \\
\hline & $\mathrm{N}$ & Average & $\begin{array}{l}\text { Standard } \\
\text { Deviation }\end{array}$ & $\mathrm{N}$ & Average & $\begin{array}{l}\text { Standard } \\
\text { Deviation }\end{array}$ & Difference \\
\hline Students of education & 36 & 2.33 & .52 & 36 & 1.90 & 1.00 & .43 \\
\hline $\begin{array}{l}\text { Student of early } \\
\text { childhood education }\end{array}$ & 20 & 2.71 & .72 & 20 & 2.43 & 1.26 & .28 \\
\hline Training teachers & 51 & 2.50 & .49 & 51 & 2.40 & .92 & .10 \\
\hline $\begin{array}{l}\text { Trainer pre-school } \\
\text { teachers }\end{array}$ & 18 & 2.74 & .50 & 18 & 3.00 & 1.15 & -.26 \\
\hline
\end{tabular}

It was found that the incidence of low-level co-teaching was higher than that of synergetic co-teaching among students of education, among students of early childhood education and among training teachers, while among early childhood pre-school teachers the incidence of synergetic co-teaching was higher than that of low-level co-teaching. 
In particular, in schools the greatest difference was between students of education (0.43), while among training teachers the difference was small $(0.10)$. The t-test found non-significant diversity in the low-level vs. synergetic co-teaching difference between the students and the pre-school teachers that is not significant: $\mathrm{t}(36)=1.81$, $\mathrm{p}>0.05$.

Table 5 compares the results of the two school groups (students of education and training teachers) and of the two pre-school groups (students of early childhood education and early childhood pre-school teachers).

Table 5. Traditional teaching, low-level co-teaching, and synergetic co-teaching in schools and pre-schools

\begin{tabular}{llllllllll}
\hline & \multicolumn{3}{c}{ Traditional teaching } & \multicolumn{3}{c}{ Low-level co-teaching } & \multicolumn{3}{c}{ Synergetic co-teaching } \\
\hline & $\mathrm{N}$ & Average & $\mathrm{SD}$ & $\mathrm{N}$ & Average & SD & $\mathrm{N}$ & Average & SD \\
\hline School & 87 & 1.85 & 0.88 & 87 & 2.36 & 0.55 & 87 & 2.19 & .98 \\
Pre-school & 38 & 2.24 & 1.01 & 38 & 2.72 & 0.71 & 38 & 2.70 & 1.22 \\
\hline
\end{tabular}

As can be seen, the averages in the pre-schools were higher than the averages in schools in all three categories (traditional teaching, low-level co-teaching, and synergetic co-teaching). In particular, it was found that both in school $(\mathrm{F}(2,172)=9.51, \mathrm{p}<0.01)$ and in pre-school $(\mathrm{F}(2,74)=3.49, \mathrm{p}<0.05)$ the incidence of shared teaching in low-level co-teaching was the highest, followed by the incidence of synergetic co-teaching. The incidence of traditional teaching was the lowest in comparison to co-teaching.

\section{Discussion and Conclusions}

\subsection{Discussion}

An analysis of these findings shows that practical experience can be characterized in several models and that there exists a wide range of co teaching - from the traditional model of practical experience, where the student is mainly passive, through an apprentice model of teaching, where the student is the teacher's helper and participates in the teaching process, to a third and new model, which we emphasize here, of synergetic co-teaching. This is sported in several modern approaches and in-school programs emphasize innovativeness that is adapted to the twenty-first century, and invite a new, alternative model of co-teaching based on the theory of connectivism (Siemens, 2008).

This theory of learning is adapted to the modern, digital age, where co-teaching plays a central role. Studies of future-looking teaching approaches show that the need for and incidence of co-teaching are because the individual is part of a group. The group learns together, individually or in smaller groups, and shares information resources with each member of the group. This method of learning is different than what existed in the past, when learning was paternalistic, centralized, and based on a personal-competitive dimension. Today, information is dispersed throughout social networks and in virtual realms (Siemens, 2004).

Such frequent changes and trends clarify the need for a widespread change of perspective, in order to best prepare today's students for tomorrow. However, we must also bridge these differences in teacher training. The present research findings show that the incidence of shared work and co-teaching was higher than that of traditional teaching in all sampled groups. These findings support the goals of the unique practical experience program to make significant changes in the nature and essence of the training processes, in educational and teaching professions. In other words, the findings show the changeover of an educational cadet from a passive observer, sitting on the sidelines, to a significant partner (Lehavi, 2010). This change was made possible by an intensive three-day experience program, which enabled students and teachers to work together for many hours over several days a week, and to create a relationship featuring shared work, guidelines, and content. In addition, training teachers also learned from the seminars we held that emphasized the importance of co-teaching in training students (Ministry of Education Think Tank, 2014).

Despite the high reported levels of co-teaching compared to traditional patterns of teaching, an analysis of the various models that exist in co-teaching still shows that the level of shared work is within the low range. In other words, although the models exemplify a new approach with greater shared work in the classroom, the training teacher still plays a more significant role in leading teaching processes. He or she is the one to direct the student's role and at least for a time works mainly with the students in the class, while the student of education serves as his or her assistant. This finding is naturally clarified in light of the relationship between the training teacher and the student of education - a more experienced veteran by contrast to a new teacher. However, it can also be explained by the traditional pattern of training teachers, which was preserved among trainers who have more experience within the education system (Alian and Daniel-Sa'ad, 2013). 
The complexity of the synergetic co-teaching approach, which expects the teacher to release some responsibility and control to the trainee teacher, could be another explanation of this pattern. Such a level of co-teaching is directed at using various pedagogical qualities, approaches, and methods that are very different from the one-teacher-in-the-classroom style of teaching (Cook \& Friend, 1995; Wenzlaff et al., 2002). This fact might also explain why training pre-school teachers reported a higher level of synergetic co-teaching: the dynamic nature of their work, which generally includes a freer and more multidisciplinary work schedule, enables greater flexibility when working in a team (Ministry of Education, 2010).

Research findings also show that participants in the unique Academy-Class training program reported using several teaching models in various configurations, as also described in the literature (Bacharach et al., 2010; Cook \& Friend, 1995; Graziano \& Navarrete, 2012). No model was found to be significantly more dominant or apparent or to characterize the training process, as we found a wide range and various levels of shared work among the training teachers, the pre-school teachers, and the students. This result correlates with the various models presented in the research literature and presents co-teaching within a structure of various models of experience. Some are more natural for a trainer-trainee relationship, depending on the trainer's work in the past, and some exhibit the start of co-teaching, using the "two-teachers-in-the-classroom" model, on an increasingly synergetic level, as expected from the new program.

Since this study is the first in its field, we cannot compare the findings to previous studies. However, the findings are significant and make a meaningful contribution to our understanding of the value of the Academy-Class program and its model, whereby students spend three full days a week over an entire year engaging in co-teaching practice, together with a training teacher or training pre-school teacher. This model clearly has a significant impact on their professional training, enabling them to adopt positive teaching patterns by modeling genuine cooperation. The findings presented above highlight a number of insights relevant for teacher training processes, as we shall now discuss.

We have seen that experiencing a clinical model of teaching involves shared work between a trained teacher and of a trainee student of education. According to the common traditional model, it was accepted to have an apprentice in the classroom: the teacher would play a significant role in teaching, with the trainee student observing passively, supervised and controlled by the teacher. Today, with the onset of the much-needed changes in training processes, we see the need to expand the theoretical approaches that describe a wide range of shared work. We recommend creating a language that characterizes events in the classroom and formulating an innovative theoretical framework that is adapted to the needs of the $21^{\text {st }}$ century. Then we must anchor these theories in an innovative and diverse field, which is not based only on differential models of experience and teaching practice, but on a model that describes the wide range of synergetic co-teaching possible between the training teacher and the trainee student. This kind of experience has many advantages. The teacher and students share the responsibility for the classroom, and the students benefit from having two teachers; they enjoy widespread arbitration, enrichment, and in-depth learning. Moreover, the teachers themselves improve their professional skills and sharpen their thought processes and working methods, absorbing innovative skills from the younger students. The students, for their part, experience firsthand the great and diverse responsibilities that are part of the teacher's role, while enjoying the protection, support, and advice of the training teacher.

This model is a suitable working model for students in the $21^{\text {st }}$ century, as shared work, shared information, team efforts and normal working relationships will be demanded from citizens of the future. Therefore, we greatly recommend creating a support system, a full security network that will not leave the trainee teacher alone and out of the picture, but give him or her a significant field of experience where he or she is constantly active, learning, experiencing, feeling, teaching, correcting, improving, and receiving reflective feedback to realize his or her future roles. This method will encourage interdisciplinary and multidisciplinary teaching, where several teachers teach in large classes, using more creative and diverse methods of teaching.

\subsection{Study Limitations}

Despite the contributions discussed above, this study's limitation is its focus on one specific research population. This convenient model was chosen in advance, in order to learn, observe, and come to conclusions regarding groundwork, the program's didactic goals, and other administrative goals we set for ourselves as the program directors. Therefore, it seems fit to expand the study to future cohorts within this program, in order to examine the trends of co-teaching in a focused and longitudinal manner and identify the possible significance for this approach. 


\section{References}

Alian, S., \& Daniel-Sa'ad, A. (2013). Changing from the traditional model in practical experience to the co-teaching model - a slogan or current need? Dapim - Journal in Educational Research, 56, 35-59.

Amar, S., \& Ben-David, N. (2016). Realistic intelligence and 21st-century skills in adapted learning environment. In S. Amar., N. B. David, \& U. Carmi (Eds.), Thoughts \& trends 2020-2025: Ohalo education conference book (pp. 23-41). Katzrin: Galilee Books PBH.

Arbiv-Elyashiv, R., \& Zimmerman, V. (2013). Dropping out from teaching in Israel: Who is the drop-out teacher? And how does the system deal with this phenomenon? Tel Aviv: Ministry of Education, Mofet Institute.

Bacharach, N., Heck, T., \& Dahlberg, K. (2010). Changing the face of student teaching through co-teaching. St. Cloud, MN: Teacher Development Faculty Publications.

Bacharach, N., Heck, T., \& Dank, M. (2004). Co-teaching in student teaching: A case study. Paper presented at the annual meeting of the Association of Teacher Educators, Dallas, Texas.

Blank, C. (2013). General and special educators' perceptions of co-teaching in inclusive middle schools (Unpublished master's thesis).

Brown, B. A. (2016). Understanding the flipped classroom: types, uses and reactions to a modern and evolving

pedagogy. $\quad$ Retrieved http://repository.stcloudstate.edu/cgi/viewcontent.cgi?article=1010\&context=ed_etds

Cleaveland, P. (2015). A multi-case study examining co-teaching approaches and practices in high school math and literature/composition classes. Doctoral Dissertations and Projects. Paper 1001.

Cook, L., \& Friend, M. (2004). Co-teaching: Principles, practices and pragmatics. Retrieved February 4, 2018 , from http://files.eric.ed.gov/fulltext/ED486454.pdf

Cook. L., \& Friend, M. (1995). Co-teaching: Guidelines for creating effective practices. Focus on Exceptional Children, 28(3), 1-17.

De Fruyt, F., Wille, B., \& John, O. (2015). Employability in the 21st century: Complex (interactive) problem solving and other essential skills. Industrial and Organizational Psychology, 8(2), $276-281$. https://doi.org/10.1017/iop.2015.33

Forbes, L., \& Billet, S. (2012). Successful co-teaching in the science classroom. Science Scope, 36(1), 61-64.

Gallo-Fox, J., \& Scantlebury, K. (2016). Coteaching as professional development for cooperating teachers. Teaching and Teacher Education, 60, 191-202. https://doi.org/10.1016/j.tate.2016.08.007

Graziano, K., \& Navarrete, L. (2012). Co-teaching in the teacher education classroom: Collaboration, compromise and creativity. Issues in Teacher Education, 21(1), 109-126.

Kamens, M. W., Susko, J. P., \& Elliott, J. S. (2013). Evaluation and supervision of co-teaching: A study of administrator practices in New Jersey. NASSP Bulletin, 97(2), 166-190. https://doi.org/10.1177/0192636513476337

Lehavi, Y. (2010). First and foremost hands-on practical experience in teachers training. Masa, Mofet Institute. Retrieved from http://portal.macam.ac.il/ArticlePage.aspx?id=2882

Ministry of Education (2010). Educational work in pre-schools: Guidelines for the educational staff. Retrieved December 26, 2017, from http://meyda.education.gov.il/files/PreSchool/KavimManhim.pdf

Ministry of Education Think Tank (2014). A unique practical experience program - partnership in strengthening teaching: Think tank's policy paper. Ministry of Education. Retrieved from http://academia-kita.macam.ac.il/Documents/\%D7\%A2\%D7\%99\%D7\%A7\%D7\%A8\%D7\%99-\%D7\%9E $\%$ D7\%A1\%D7\%9E\%D7\%9A-\%D7\%9E\%D7\%93\%D7\%99\%D7\%A0\%D7\%99\%D7\%95\%D7\%AA-\%D7 \%90\%D7\%97\%D7\%A8\%D7\%99-\%D7\%AA\%D7\%99\%D7\%A7\%D7\%95\%D7\%A0\%D7\%99\%D7\%9D.p df

Murawski, W. W., \& Lochner, W. W. (2011). Observing co-teaching: What to ask for, look for and listen for. Intervention in School and Clinic, 46(3), 174-183. https://doi.org/10.1177/1053451210378165

Petrick Jr., D. L. (2015). An investigation into co-teacher relationship collaboration factors: Co-teachers' perceptions. Indiana, PA: Indiana University of Pennsylvania.

Roth, W. M., \& Tobin, K. (2005). Teaching together, learning together. New York, NY: Peter Lang. 
Rytivaara, A., \& Kershner, R. (2012). Co-teaching as a context for professional learning and joint knowledge construction. Teaching and Teacher Education, 28, 999-1008. https://doi.org/10.1016/j.tate.2012.05.006

Sachs, G. T., Fisher, T., \& Canon, J. (2011). Collaboration, mentoring and co-teaching. Journal of Teacher Education for Sustainability, 13(2), 70-86. https://doi.org/10.2478/v10099-011-0015-z

Scantlebury, K., Gallo-Fox, J., \& Wassell, B. A. (2008). Co-Teaching as a model for preservice science teacher education. Teaching and Teacher Education, 24(4), 967-981. https://doi.org/10.1016/j.tate.2007.10.008

Siemens, G. (2008). Learning and knowing in networks: Changing roles for educators and designers. ITFORUM for Discussion.

Tov Li, A., \& Frisch, Y. (2008). Co-Teaching in a teachers' training course. are we facing "more of the same" or "another way"? In the course: "Openness to Something Else - Nurturing Excellence in the Classroom." Shaanan College Yearbook, 13, 199-230.

Villa, R. A., Nevin, A. I., \& Thousand, J. S. (2004). A Guide to co-teaching. New York, NY: Corwin Press.

Walsh, J. M., \& Jones, B. (2004). New models of cooperative teaching. Teaching Exceptional Children, 36(5), 14-20. https://doi.org/10.1177/004005990403600502

Wehunt, M. D., \& Weatherford, J. S. (2014). Co-teaching for student engagement. The Researcher, 26(1), 45-48.

Wenzlaff, T., Berak, L., Wieseman, K., Monroe-Baillargeon, A., Bacharach, N., \& Bradfield-Kreider, P. (2002). Walking our talk as educators: Teaming as a best practice. In E. Guyton \& J. Ranier (Eds.), Research on meeting and using standards in the preparation of teachers (pp. 11-24). Dubuque, IA: Kendall-Hunt Publishing.

\section{Copyrights}

Copyright for this article is retained by the author, with first publication rights granted to the journal.

This is an open-access article distributed under the terms and conditions of the Creative Commons Attribution license (http://creativecommons.org/licenses/by/4.0/). 